\title{
Establishing the Relation Between Market-Based Performance Measure and Accounting Performance Measure
}

\author{
Sami E. Alajlani \\ Business Department, Higher Colleges of Technology, Sharjah, United Arab Emirates
}

\begin{abstract}
The purpose of this study is to examine the relationship between market-based and accounting-based performances. Sample was comprised of 49 companies listed on Amman Stock Exchange (ASE) was taken. Data was collected from financial statements and official bulletins of stock market prices published between 2008 to 2016. The sectors included the Pharmaceutical \& Medical Industries, Chemical Industries, Paper \& Cartoon Industries, Food \& Beverage, Tobacco \& Cigarettes, Mining \& Extraction Industries, Engineering \& Construction, Electrical Industries, Textile, and Leather \& Clothing. This study employed panel data analysis using fixed-effect estimation, random-effect estimation, and a pooled regression model. The results of this investigation demonstrated that a firm's accounting performance measures (ROA and P/E) had a significant positive relationship with the firm's market performance measure of $\mathrm{Q}$ ratio during the 9 years of the research as well as there was no significant relation between $\mathrm{Q}$ Ratio and P/E, P/B, ATO, and PM. An interesting finding further showed that the ROE measures have negatives and have a highly significant relationship with Tobin's $Q$ ratio.
\end{abstract}

Keywords: Accounting performance ratio, Tobin's Q, Market Performance ratio.

DOI: $10.7176 / \mathrm{RJFA} / 10-20-04$

Publication date:October $31^{\text {st }} 2019$

\section{Introduction}

Over the last two decades, researchers have extensively discussed the use of accounting and market measures as indicators of firm financial performance in terms of whether or not these to be considered as valid indicators of firm financial performance. Ball and Brown (1968) have conducted an empirical research in order to investigate the relationship between stock prices and accounting information, in context of New York Stock Exchange. They found the significant influence of profits on stock prices. other empirical studies have also been undertaken for testing this relationship between accounting financial information and its impacts on the market stock price. Ball and Brown (1968) indicated that the information about an individual firm that becomes available during the year captured that years income number. The variance in the results of these studies on the relationship between accounting information and market measures reflected the effect of using different independent variables incorporated in different models with data of one financial year. Further in this context, Dang, Tran, and Nguyen (2018) have asserted that the relevance and significant impact of financial information on stock prices has not been clearly manifested. Many authors have articulated that relationship between accounting-based and market-based performance measures, particularly regarding how closely they are related, is still under debate within the field today. (Chakravarthy, 1986; Combs et al., 2005; Keats, 1996; Rowe and Morrow, 1999).

Literature explains certain reasons for two measures correlated only at a relatively low extent. In discussing reasons, Miller (1987) have argued that individual measurements are more valuable than objective measurements due to the lack of availability and reliability of accounting information because owners and management could manipulate these. Moreover, researchers generally treat accounting profitability measures of past, short-term financial performance and market performance as indicators of future or long-term performance (Hoskisson et al., 1994; Keats, 1988). The results of many empirical studies support the relationship between accounting and market measures of financial performance. In the association of accounting and market measures, findings are inconsistent and incongruent (Rahman et al. 2017). Researchers have shown significant positive association between firms' accounting measures, profitability ratios \& their market value. Signaling theory also reflects the positive association between firm accounting and market measures by postulating that firms' better financial performance attracts investors which increases firm market value (Baker \& Anderson, 2010; Modigliani, 1980; Vishnani \& Shah, 2008).

Based upon previous arguments, the question whether or not firms' accounting measures or their profitability ratios may have any significant relationship with firm market value as shareholders are interested in the maximization of their wealth, which is directly reflected by increased firm market value. (Baker \& Anderson, 2010; Irungu, 2007). In contrast, this paper further investigates the relationship between accounting measures and market measures of firm financial performance. We have selected P/E, EPS, ROE, P/B, ATO, PM and ROA as accounting measures and Tobin Q ratio as firm market-value performance measures. OLS panel data analysis has been employed by using fixed-effect estimation, random-effect estimation and a pooled regression model for investigating the relationship in a sample of 49 companies listed on Amman stock exchange for nine years from 2008 to 2016 , of a total of 3500 observations. 
Interested groups such as managers, shareholders, creditors, and tax authorities, as well as various firms, have given answers to essential questions about financial performance which is considered a subjective measure of how well a firm can use assets from its primary mode of business and generate revenues.

\subsection{Research Objectives}

This research aims to explore the association between the market valuation measure of Amman Stock Exchange Industrial Sectors utilizing the Tobin's Q ratio as a performance indicator with selected accounting measure of firm financial performance among Jordanian industrial firms. Specifically, the research objectives addressed in this research work were as follows:

a) to examine the relationship between accounting measure and market measures of firm financial performance in general and the long run performance

b) to determine whether an accounting measure of financial performance has a positive relationship with firm market value.

\subsection{Hypothesis}

H1: There is a significant impact of selected financial indicators (variables) on the company's performance measured by Tobin's Q

The research paper is anchored on the following concepts postulated by authors on the importance of accounting information on security price determination which is of interest to both security analysts and accountants.

\section{Literature review}

The Q ratio concept was first introduced by Tobin (1969) as an indicator of a firm's ongoing investments. Different financial analysts have been using this ratio as a proxy of market company's performance measure (Tobin and Brainard, 1968; Tobin and Brainard, 1977; Tobin, 1969). Joseph and Sauaia (2003) have used Tobin's Q ratio as a company's performance indicator. Further Sauaia and Castro (2014) and Behrooz and Javad (2015) have also used Tobin's Q ratio as a measure of company performance. The use of Tobin's Q to measure performance is becoming increasingly popular. It is defined as "the ratio of market value to the replacement cost of tangible assets". Tobin's Q is used to value investment opportunities, management's performance, and the mispricing of stocks. Tobin's Q's accounts for both the market and accounting data. Chung and Pruitt (1994) developed a simple approximating of Tobin's Q. In their study, they proved the approximate $\mathrm{Q}$ by considering the figures from a company's financial statement by the use of ratio analysis. Indeed, financial statement analysis is vital, since past performance is usually a good indicator of future performance, and the current position is the platform upon which future performance will be built (Horngren and Sundem, 1990). Since the accounting profits or profitability ratios are simple and common tools to be used for evaluating the efficiency of the firm and management (Hax, 2003).

As a result of this, in finance research, the use of market measures has captured the attention of academia and its relationship with accounting measures. Financial ratio analysis, being one of the most frequent techniques, involves studying various relationships between different items of financial statements using a static method. Financial ratios are used to evaluate the various aspects of a company's operational and financial performance, for example, its liquidity, efficiency (activity), leverage (financial structure-solvency), and profitability. Ratio analysis contains a means of calculating and interpreting financial ratios to analyze and monitor the firm's performance. The basic inputs to ratio analysis are the firm's income statement and balance sheet (Gitman, 2009). Ratios perform a crucial role in the management accounting function. It identifies and highlights the areas of poor and adequate performances (James, 2013).

Behrooz and Rezaei (2015) have investigated the performance of companies listed on Tehran stock exchange. The result have shown no significant relationship between the Tobin's Q ratio and accountings performance measure. Singhal, Fu, and Parkash (2016) provided evidence concerning the relationship between the Q ratio and future operating performance publicly traded US firms; their study further showed that firms with higher Q ratios experience superior operating performance in the long run. However, some researchers have manifested an inverse relationship between current accounting measures or profitability ratios and firm market value (Chakravarhy, 1986; Combs, Crook, \& Shook, 2005; Keats, 1988; Lama, Tibbits, \& Puttee, 2012). Furthermore, Wolfe and Carlos (2003) have asserted that Tobin Q could be used as a diagnostic tool and predictor of company success when applied to The Business Policy Game. As a diagnostic tool, firms with low Q ratio might be considered candidates for instructor-led coaching or counseling. Practically speaking, the Q is sensitive to the swing effects of its equation's denominator, i.e., the firm's total assets of cash, receivables, inventory, and plant book value." In words of Wolfe and Sauaia (2003), "If players can be shown how to be more efficient in their use of cash, how to produce better forecasts which allows them to lower their average inventories or obtain more output given the firm's plant and equipment, its $\mathrm{Q}$ will increase. As a predictor of the firm's ultimate success, it might be used as a more realistic Wall Streeter's view of the firm's worth"., Rahman, Ibrahim, and Ahmad () have discussed the inconsistency of 
relationship between accounting and market measures of firm financial performance. They have investigated the relationship by examining the impact of profitability (EPS, ROE, and ROA) on firm market value. Findings revealed that ROE has a significant relation while ROA has an insignificant positive association with firm market value. These results also showed the relationship between EPS and firm market value is negative and statistically significant; it showed that investors give value to the firms which maximize return on their equity, and thus based on these findings, investors, banks, insurance companies, financial institutions can deploy their economic resources.

Li,L.(2013).have compared market-based and accounting-based performances of listed commercial banks among eight Asian emerging markets (China, India, Indonesia, Korea, Malaysia, the Philippines, Taiwan, and Thailand) over the period 2005-2010. Market-based performance was measured by Tobin's Q ratio, and three conventional ratios measure accounting-based performance a bank: return on assets and return on equity and net interest margin. It was found out that the Indonesian banks have the highest average Tobin's Q ratio of 1.14, return of 1.82 percent and net interest margin of 5.34 percent, however, Chinese and Indian banks maintain 18.22 percent, the highest average return on equity. Korean, Taiwanese, and Thai banks have an average Q ratio of 1.00, which is the lowest. Further results showed that Taiwanese banks also have the lowest average ROA (return on assets) of negative 0.57 percent, return on equity of negative 7.80 percent and net interest margin of 1.97 percent. Q is shown to be significantly positively related to return on assets and return on equity, but there is no significant relationship between $\mathrm{Q}$ and net interest margin. Therefore, determinants of each type of performance are found to be different. Conclusively, the different regression results for banks in every single emerging market indicate that the market-based and accounting-based performances of commercial banks in different emerging markets are affected by different factors in different ways.

\section{Research methodology}

In current study, 49 listed companies (Amman Stock Exchange) from all industrial sectors were used . These sectors were clustered based on the ASE classification as published in their annual publication from 2008-2016. The sectors included the Pharmaceutical \& Medical Industries, Chemical Industries, Paper \& Cartoon Industries, Food \& Beverage, Tobacco \& Cigarettes, Mining \& Extraction Industries, Engineering \& Construction, Electrical Industries, Textile, and Leather \& Clothing. Amman Stock Exchange (ASE) Annual report (2016).

Published annual reports of the sample sectors were taken from 2008 to 2016 , with the year-end closing prices from the annual financial reports and the number of shares outstanding that were obtained from the price bulletin published by the authority of Amman Stock Exchange (ASE) (www.exchange.jo). In context of market performance of industrial sectors of the Amman Stock Exchange, the Q ratio was used to measure the market value of a company's assets to the replacement cost of the company's assets. The numerator of the ratio is the market value of its outstanding stock and debt, and the dominator is the book value of the company assets.

Tobin's Q ratio was used to calculate the valuation of the industrial sectors of the various companies for nine consecutive years applying the simple approximation, as follows:

Tobin' s $Q=($ market value $) /($ replacement cost $)$. Econometric Modeling including control variables, the following is the econometric model of the study.

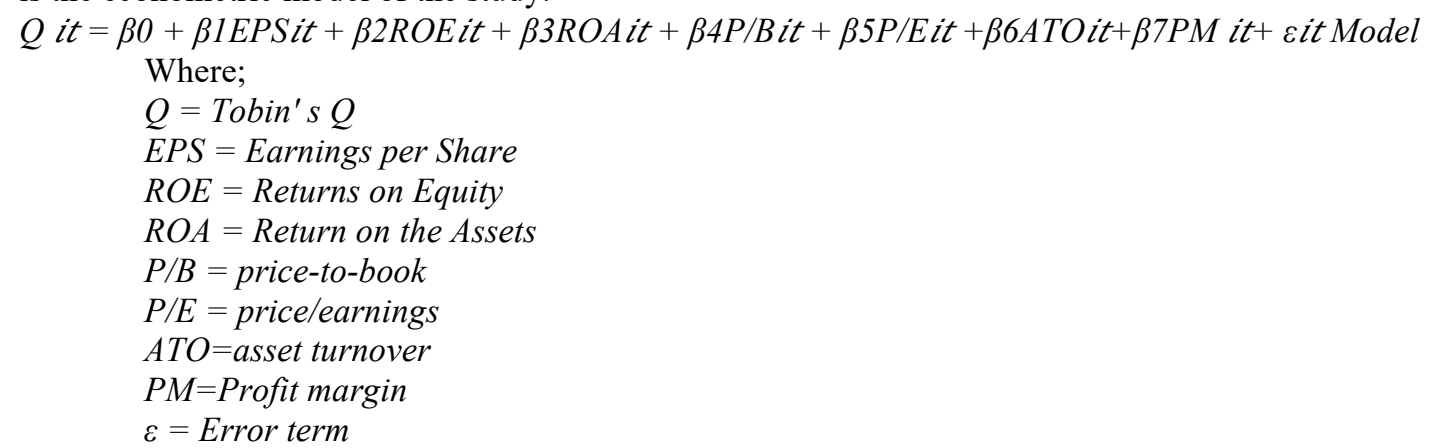

This study employed panel data regression analysis by using fixed-effect model estimation, random-effect estimation model, and a pooled regression model. The usual identification tests and Hausman's Chi-square statistics for testing whether the fixed effects model estimator is an appropriate alternative to the random effects model were also computed for each model.

\section{Results and Discussion}

Econometric tools has been applied in the analysis of the variables shown in the model. Descriptive statistics and Pearson's correlation matrix were applied to analyze the data. Descriptive statistics describe the nature of the data by explaining minimum and maximum limits along with the mean values of the variables. The correlation matrix shows the simple correlation among all variables of the study. The E-views package was used in the estimation 
process and results that are presented in the tables.

Table 1 . The indicators along with values of mean, median, minimum, maximum and standard deviation.

\begin{tabular}{|r|l|l|l|l|l|}
\hline Indicators & Mean & Median & Maximum & Minimum & Std. Dev. \\
\hline Q & 0.871 & 0.680 & 7.190 & -0.050 & 0.781 \\
\hline EPS & 0.097 & 0.040 & 3.740 & 10.000 & 0.654 \\
\hline P/E & 154.681 & 10.645 & 57637.000 & -1928.250 & 2759.968 \\
\hline P/B & 2.550 & 0.980 & 500.130 & -0.690 & 24.132 \\
\hline PM & 1.901 & 3.020 & 362.160 & -937.300 & 56.491 \\
\hline ROA & 3.627 & 3.295 & 514.000 & -195.300 & 27.920 \\
\hline ROE & -60.152 & 3.490 & 5721.000 & -34544.150 & 1673.059 \\
\hline ATO & 0.628 & 0.600 & 2.140 & 0.000 & 0.371 \\
\hline
\end{tabular}

Focusing on the mean values and standard deviation, which considered the most important, we find that the mean value of Tobin's Q indicator (dependent variable) was $(0.871 \pm 0.781)$, for the EPS indicator the mean value was $(0.097 \pm 0.654)$. For the price $\mathrm{E}$, the mean value was $(154.681 \pm 2759.968)$, the price book's mean value was observed to be $(2.550 \pm 24.132)$, concerning the PM variable, the mean value was $(1.901 \pm 56.491)$. The ROA variable had satisfied a mean of $(3.627 \pm 27.920)$. The mean value for the ROE variable was observed to be ($60.152 \pm 1673.059)$ and the mean value which was observed for the ATO variable was $(0.628 \pm 0.371)$. It is observed that the standard deviation values are considered to be high concerning the mean concluding a great and high variation among the sample's companies.

This could be explained by the different policies and approaches that these companies adopt and use to execute their operations which finally affects the performance presented by Tobin's Q variable in the current study.

Table 2. Correlation coefficients matrix among the study variables, Pearson Correlation Matrix

\begin{tabular}{|c|c|c|c|c|c|c|c|c|c|}
\hline \multicolumn{2}{|c|}{$\begin{array}{l}\text { Variables / } \\
\text { correlations }\end{array}$} & $\begin{array}{l}\text { TOBINS } \\
\mathrm{Q}\end{array}$ & EPS & PRICE E & PRICE BOOK & PM & ROA & ROE & ATO \\
\hline \multirow[b]{2}{*}{$\mathrm{Q}$} & $\mathrm{r}$ & 1 & & & & & & & \\
\hline & prob & - & & & & & & & \\
\hline \multirow[b]{2}{*}{ EPS } & $\mathrm{r}$ & 0.276 & 1 & & & & & & \\
\hline & prob & 0.000 & & & & & & & \\
\hline \multirow[b]{2}{*}{$\mathrm{P} / \mathrm{E}$} & $\mathrm{r}$ & -0.016 & -0.007 & 1 & & & & & \\
\hline & prob & 0.734 & 0.890 & & & & & & \\
\hline \multirow[b]{2}{*}{$\mathrm{P} / \mathrm{B}$} & $\mathrm{r}$ & 0.057 & -0.040 & -0.003 & 1 & & & & \\
\hline & prob & 0.231 & 0.404 & 0.943 & & & & & \\
\hline \multirow[b]{2}{*}{ PM } & $\mathrm{r}$ & 0.047 & 0.148 & 0.000 & -0.040 & 1 & & & \\
\hline & prob & 0.326 & 0.002 & 0.995 & 0.397 & & & & \\
\hline \multirow[b]{2}{*}{ ROA } & $\mathrm{r}$ & -0.053 & 0.188 & -0.006 & -0.081 & 0.137 & 1 & & \\
\hline & prob & 0.270 & 0.000 & 0.905 & 0.090 & 0.004 & & & \\
\hline \multirow[b]{2}{*}{ ROE } & $\mathrm{r}$ & -0.006 & 0.095 & 0.002 & -0.970 & 0.051 & 0.098 & 1 & \\
\hline & prob & 0.896 & 0.046 & 0.965 & 0.000 & 0.283 & 0.039 & - & \\
\hline \multirow[b]{2}{*}{ ATO } & $\mathrm{r}$ & -0.016 & 0.106 & -0.028 & 0.058 & 0.046 & 0.078 & -0.016 & 1 \\
\hline & prob & 0.739 & 0.026 & 0.556 & 0.226 & 0.336 & 0.101 & 0.743 & \\
\hline
\end{tabular}

Table (2) declares the correlation coefficients among the study variables. It is assumed that the interrelationships among the independent variable are low to express the individuality and specificity. Inspecting the correlation values, it was clear that the most substantial relationship was observed between ROE and price book (- 0.970) such that this relationship is robust and statistically significant taking into account that this relationship is negative meaning that if one of the two variables increases the other variable decreases and vice versa. Book value can be twisted and prodded into many different numbers depending on how the books of accounts are prepared. Copeland and Weston (1998). An overall look of the rest correlation values reveals that most of these values express fragile relationship; such that in some cases it was almost (0.000) like the PM variable and the Price. E, in addition to that some bivariate relationships are positive while the other relationships are negative. As a result, this correlation coefficients matrix table tells that the study variables satisfy low interrelations among each other except the relationship between ROE and price book and that most of these relationships were not statistically significant. 
Table 3. The Hausman test for the random fixed effects

\begin{tabular}{|l|c|c|c|}
\hline Test Summary & Chi-Sq. Statistic & Chi-Sq. d.f. & Prob. \\
\hline Cross-section random & 15.917 & 7 & 0.025 \\
\hline
\end{tabular}

Table (3) indicates the results of the Hausman test for the random effects; the test value is expressed using the chi-square value (15.917). This value suggests that the null hypothesis of the Hausman test (that is the observed effects are considered to be random) is rejected based on the related probability value $(0.025)$ which was $<0.05$. Accordingly, the desired panel data model analysis is a fixed effects model. The following table tests the statistical significance between the coefficient values calculated for the fixed and random effects. The Durbin-Wu-Hausman test is a statistical hypothesis test in econometrics named after James Durbin, De-Min Wu, and Jerry A. Hausman, in which the test evaluates the consistency of an estimator when compared to an alternative, less efficient estimator which is already known to be consistent.

Table 4. The cross-section random effects test comparisons

\begin{tabular}{|r|r|r|r|r|}
\hline \multicolumn{1}{|c|}{ Variable } & Fixed & \multicolumn{1}{c|}{ Random } & Var (Diff.) & \multicolumn{1}{c|}{ Prob. } \\
\hline EPS & 0.080 & 0.129 & 0.000 & 0.000 \\
\hline P/E & 0.000 & 0.000 & 0.000 & 0.985 \\
\hline P/B & 0.017 & 0.018 & 0.000 & 0.159 \\
\hline PM & 0.001 & 0.000 & 0.000 & 0.887 \\
\hline ROA & -0.002 & -0.002 & 0.000 & 0.475 \\
\hline ROE & 0.000 & 0.000 & 0.000 & 0.184 \\
\hline ATO & -0.018 & -0.059 & 0.004 & 0.497 \\
\hline
\end{tabular}

Table (4) reflects the values of magnitudes of impacts of the financial indicators (variables) influencing the dependent variable for companies' performance using Tobin's Q. The results provided by both the fixed and random effects models. Additionally, the table reflects the probability values related to testing the difference of beta coefficients by both models. It was clear that the impact coefficients of the EPS variable were significantly different as the probability value was $(0.000)<0.05$, noting that despite the more significant impact of this variable was greater $(0.129)$ by the random effects model but this will be dismissed as the suggested model was fixed effects model. Likewise, the other impact values (beta coefficients) were close to each other, such that the probability values do not suggest these differences.

Table 5. Model specifications using the fixed cross-section

\begin{tabular}{|l|r|}
\hline model specifications & value \\
\hline R-squared & 0.550 \\
\hline Adjusted R-squared & 0.486 \\
\hline S.E. of regression & 0.560 \\
\hline Sum squared resid & 120.467 \\
\hline Log-likelihood & -339.344 \\
\hline Durbin-Watson stat & 1.253 \\
\hline F-statistic & 8.538 \\
\hline Prob(F-statistic) & 0.000 \\
\hline
\end{tabular}

Table (5) shows the results of the fixed effects model for the variables assumed to affect Tobin's Q. The model's R2 value was $(55.0 \%)$ indicating a good percentage, in the same context the value of adjusted R2 was $(48.6 \%)$ these values reflect the percentage of the variation in the dependent variable that can be related or explained by the independent variables. In this instance, this result brings about an implication concerning the result of the hypothesis that the independent financial indicators (independent variables) affect the dependent variable Tobin's Q. this hypothesis is accepted because the probability of (F-statistics) which was $(0.000)$ was $<$ 0.05 . (i.e., we reject the null hypothesis that there is no effect of the independent variables on Tobin's Q). 
Table 6. The regression results with fixed effects model

\begin{tabular}{|c|c|c|c|c|}
\hline Variable & Coefficient & Std. Error & t-Statistic & Prob. \\
\hline EPS & 0.08042 & 0.053 & 1.529 & 0.127 \\
\hline P/E & 0.01706 & 0.000 & -0.495 & 0.621 \\
\hline P/B & 0.00051 & 0.005 & 3.422 & $0.001^{*}$ \\
\hline PM & -0.00224 & 0.001 & 1.004 & 0.316 \\
\hline ROA & 0.00023 & 0.001 & -2.133 & $0.034^{*}$ \\
\hline ROE & -0.01780 & 0.000 & 3.195 & $0.002^{*}$ \\
\hline ATO & -0.00001 & 0.128 & -0.139 & 0.890 \\
\hline C & 0.85309 & 0.083 & 10.250 & $0.000^{*}$ \\
\hline
\end{tabular}

Table (6) indicates the magnitudes of the impact values for each independent variable and its statistical significance using the probability of t-statistics. Referring to the probability values and comparing it with 0.05 , easily it can be detected that the probability values of three variables affect the dependent variable; these variables were: the price book with a probability value of $(0.001)$, the ROA variable with a probability value of $(0.034)$, and for the ROE variable with a probability value of $(0.002)$. These values were less than 0.05 which suggests that the mentioned impact values are considered to be statistically significant. The impact value revealed by the price _book was (0.00051), this a positive value suggesting a positive contribution to the dependent variable. The impact values observed for the ROA $(0.00023)$ which is an appositive value reflecting a positive contribution to the dependent variable.

With regards to the impact value for the ROE, it was $(-0.01780)$ which reflects a negative contribution to the dependent variable taking into account that despite the negative contribution to the dependent variable it was the greatest (in the absolute form) among the mentioned three significant affecting variables. The correlation with the independent variables, the fixed-effect model, which is also called Least Squares Dummy Variables Model, is more efficient than the random-effect model.

\section{Conclusions and recommendations}

The findings of current research have supported $\mathrm{H} 1$ and rejected the null H0 that the Fixed-effect model reports the highest sensitivity and more efficient than the random-effect model. The mixed nature of findings reveals that the accounting performance measures of ROA, ROE and P/B has a significant relationship while EPS, P/E, PM, and ATO have an insignificant relationship with firm market performance measure Q ratio. Only ROE has a significant negative relationship with the firm market value. The findings of this research have also supported the concepts of financial analysts, that financial performance, on a broader sense, the degree to which financial objectives, being or has been accomplished and is an essential aspect of financial risk management. It is the process of measuring the results of a firm's policies and operations in monetary terms. The research work has further presented a measure of the firm's overall financial health over a given period and can also be used to compare similar firms across the same industry or to compare industries or sectors in aggregation. It can also attest to enrich the financial literacy in this field by investigating the market performance measure, and accounting measure in industrial sector listed firms by taking Jordan as a case study.

For future research directions, the researcher suggests to include further accounting performance measures, and moreover to increase the time span. More sectors such as banking and services to explore the level of performance of firms and to be reflected in the firm's financial statement that shows how a firm has used the funds entrusted to it by its stockholders(shareholders and lenders, informing these stakeholders on what it is current financial position, as included in the three basic financial statements as the (1) balance sheet, which shows firm's assets, liabilities, and net worth on a stated date; (2) income statement (also called profit \& loss account), such statement shows how the net income of the firm is arrived at over a stated period, and (3) cash flow statement, which shows the inflows and outflows of cash caused by the firm's activities during a stated period.

\section{References}

Ball, Ray, and Philip Brown. 1968. “An Empirical Evaluation of Accounting Income Numbers.” Journal of accounting research: 159-78.

Baker, H. K., \& Anderson, R. (2010). An overview of corporate governance. Corporate governance: A synthesis of theory, research, and practice, 3-17.

Bernard, V. (1989). Capital markets research in accounting during the 1980s: A critical review. The State of Accounting Research as we enter the 1990s. University of Illinois at Urbana-Champaign, Urbana, IL.

Frecka, T.J. (Ed.), The State of Accounting Research as we enter the 1990s. University of

Illinois at Urbana-Champaign, Urbana, IL.

Chakravarhy, B. (1986). Measuring strategic performance. Strategic Management Journal, 7(1), 437-458. 
Chung, Kee H.; Pruitt, Stephen W. (1994) “A Simple Approximation of Tobin’s q.” Financial Management. 7074

Dang, Ngoc Hung, Manh Dung Tran, and Thi Lan Anh Nguyen. 2018. "investigation of the impact of financial information on stock prices: the case of vietnam." Academy of Accounting and Financial Studies Journal $22(2)$.

Hax, H. (2003). Measuring the firm's performance: Accounting profit versus market Value. Journal of Institutional and Theoretical Economics, 159(4), 675-682.

Keats, B. (1988). The vertical construct validity of business economic performance measures. Journal of Applied Behavioral Sciences, 24(1), 151-160.

Richard A. Lambert and David F. Larcker Journal of Accounting Research Vol. 25, Studies on Stewardship Uses of Accounting Information (1987). 85-125

Sauaia, A. C. A., \& Castro, F. H. F. (2014, March). Is Tobinâ€TM s Q a Good Indicator of a Companyâ€ $€^{\mathrm{TM}} \mathrm{s}$ Performance? In Developments in Business Simulation and Experiential Learning: Proceedings of the Annual ABSEL conference (Vol. 29).

Tobin, J. 1969. A general equilibrium approach to monetary theory. Journal of Money Credit and Banking 1 (1), 15-29. Tobin, J. 1978. Fiscal policies and the economy: the transmission mechanism. Southern Economic Journal 37 (April): 421-31.

Tobin, J., and Brainard, W. 1968. Pitfalls in financial model building. American Economic Review 58 (May): 99-122.

Tobin, J., and Brainard, W. 1977. Asset markets and the cost of capital. In B. Belassa and R. Nelson (eds.), Economic Progress Private Values and Public Policies: Essays in Honor of William Fellner. Amsterdam: North-Holland

Lama, Tibbits, G., \& Puttee, C. (2012). The impact of the Australian stock exchange's corporate governance codes on investor confidence. International Review of Business Research Papers, 8(5), 111-122.

Lang L.H.P.; Stulz R.M. (1993) “Tobin's Q, Corporate Diversification and Firm Performance.” National Bureau of Economic Research 1050 Massachusetts Avenue Cambridge, MA 02138

Lindenberg, E. \& Ross, S. (1981) “Tobin's q Ratio and Industrial Organization.” Journal of Business. Volume 54, 1981.

Li, L. (2013). Market-based vs. accounting-based performance of banks in Asian emerging markets. Asian Journal of Business Research ISSN, 1178(8933), 8933.

Modigliani, F. (1980). Introduction. In A. Abel (ed.), The Collected Papers of Franco Modigliani, volume 3, Cambridge, Massachusetts: MIT Press. ( xi-xix).

Vishnani, S., \& Shah, B. K. (2008). Value relevance of published financial statements- With particular emphasis on the impact of cash flow reporting. International Research Journal of Finance \& Economics, 17(1), 84-90.

Walker, M. (1997). Clean surplus accounting models and market-based accounting research: A review. Accounting and Business Research, 27(4), 341-355.

\section{Electronic References}

http://www.exchange.jo//en/bulletins/> Accessed on 1/08/2018

https://www.ase.com.jo/ Accessed 1/08/2018 